Ann. Biol. anim. Bioch. Biophys., 1979, 19 (1 B), 167-172.

\title{
Early effects of undernutrition on the development of cerebellar Bergmann glia cells
}

\author{
par J. CLOS, Christiane LEGRAND, J. LEGRAND
}

Laboratoire de Physiologie comparée,

Université des Sciences ef Techniques du Languedoc,

34060 Montpellier Cedex, France.

Summary. The morphological maturation of Bergmann glia cells, which might play a particularly important role in the histogenesis of the cerebellar cortex, was studied in GolgiCox preparations and electron micrographs of the cerebellum of normal and undernourished young rats. An unexpected acceleration in the morphological development of Bergmann glia cells was observed in the undernourished animals during the early postnatal period.

\section{Introduction.}

The influence of nutritional deprivation on the biochemical and morphological development of the nervous system has been widely investigated (see recent review by Wurtman and Wurtman, 1977). Most of the information available concerns changes in the formation and maturation of neurones and in the establishment of their connections. There are fewer data in the literature describing the effect of nutritional state on glial development (review in Clos, 1977). In the rat, early food deprivation reduces the final DNA content of the brain, especially of the cerebellum (Gourdon ef al., 1973 ; Patel et al., 1973 ; Clos et al., 1977). The cellular composition of the cerebellum is also modified in the 35-day-old undernourished rat (Clos et al., 1977). Undernutrition, although affecting the formation of interneurones (basket and granule cells) interacts preferentially with the acquisition of glial cells, $i$. e. glial cells in the molecular layer and Bergmann glia cells around the Purkinje cells and astrocytes in the internal granular layer are less dense than in the normal subject. Electron microscopic studies demonstrate that this glial hypoplasia is accompanied by a decrease in the area of molecular layer covered by the glial processes, i. e. essentially Bergmann glia cell processes (Clos, Rebière and Legrand, 1973).

The Bergmann glia cells may play a particularly important role in the ontogenesis of the cerebellar cortex. Most of them differentiate and proliferate during the early postnatal period (Das, 1976). Their formation and maturation could be particularly sensitive to food deprivation during the fetal and neonatal periods. Their processes cover a large area of the molecular layer surrounding the dendrites of Purkinje 
cells, and they thus could affect the establishment of the synapses between the interneurones and the Purkinje cells. Bergmann glia cell soma is a satellite of the Purkinje cell body and might have a nutritive role for the latter. Lastly, Bergmann glia cells may first control the migration and laying down of macroneurones (Swarz and del Cerro, 1976) and later of interneurones (Rakić, 1971 ; Sotelo and Changeux, 1974).

We report here the morphological maturation of Bergmann glia cells studied in Golgi-Cox preparations and electron micrographs of the cerebellar cortex of control and undernourished rats 5 to 21 days after their birth.

\section{Material and methods.}

Animals. - Young rats of a Wistar strain bred in our laboratory were undernourished by employing two methods. In the first one, the size of the litters was increased to 16 pups per dam on the day of birth; the offspring were separated from the dam $12 \mathrm{hrs}$ per day and placed either in an incubator (when they were less than 14 days old) or a cage near that of the mother. In the second method, undernutrition was obtained by quantitative restriction of the mother's diet from day 6 of gestation, and nursing
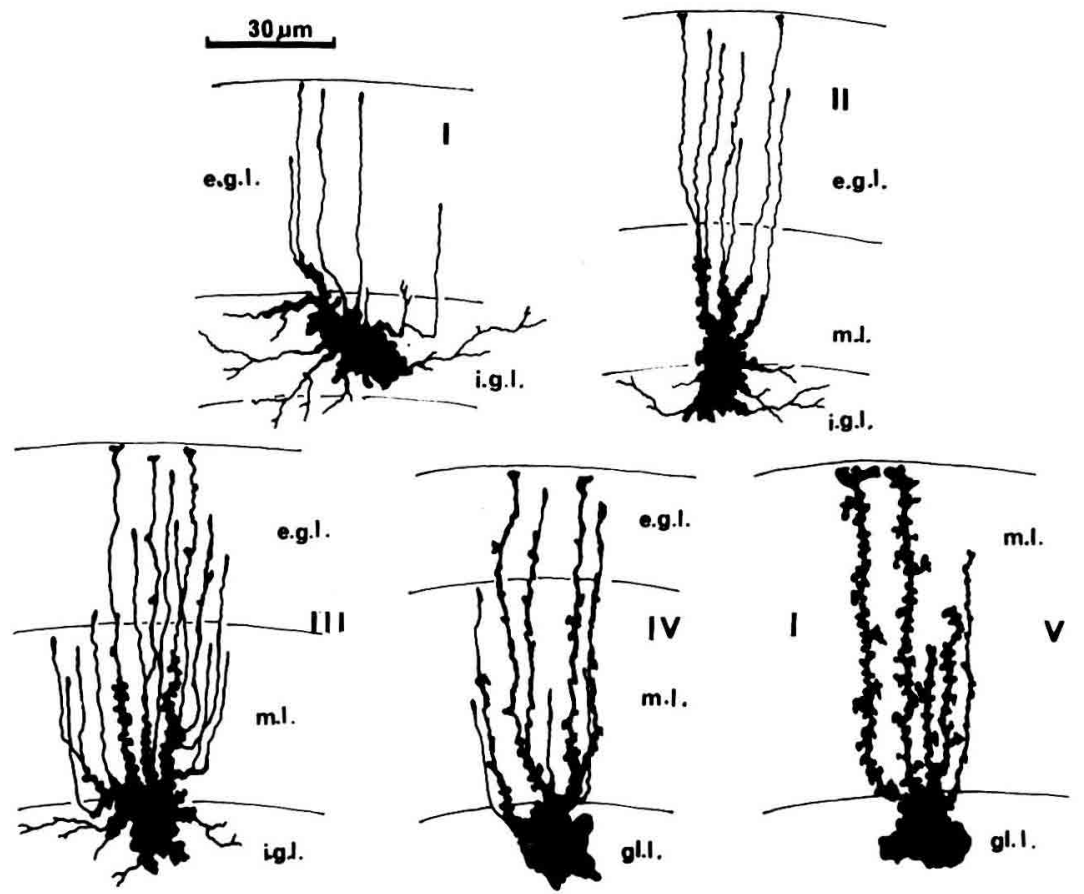

FIG. 1. - The 5 stages of Bergmann glia cell development. Midsagittal sections of the cerebellar vermis. Golgi-Cox preparations. Each drawing was made from one cell under a WILD M20 microscope with a drawing tube. No composite drawings were made from several cells. Stages I, II and III : growth and multiplication of the filiform processes towards the surface of the cerebellum. Stages IV and $V$ : resorption and differentiation of the filiform processes. e. g. I. : external granular layer; m. I. : molecular layer; i. g. I. : internal granular layer ; gl. I. : ganglionic layer. 
families of 8 animals each were constituted on the day of birth. The quantity of food (Labena) given daily to the mother amounted to about 50 p. 100 of the ad libitum daily food intake of a pregnant or lactating rat. We used controls from normal litters composed of 8 offspring each. The animals were killed when 5, 8,10,14 and 21 days old.

Histological methods. - Cerebella were impregnated according to the Golgi-Cox procedure, embedded in celloidin and cut midsagittally at 100 or $200 \mu \mathrm{m}$. All the positively identified and entirely impregnated Bergmann glia cells were counted in one midsagittal section of the vermis and assigned to 5 arbitrarily chosen stages of development (fig. 1). Although there was a considerable degree of overlap between these stages, they were sufficiently well defined to allow a valid classification of the cells (for a detailed description of the morphological development of Bergmann glia cells the reader is referred to Das, 1976).

Electron microscopic methods. - Cerebella of 5-day-old normal and undernourished rats were immersed in a buffered glutaraldehyde-formaldehyde mixture for about 20 hrs. After post-fixation in 1 p. 100 osmium tetroxide, ultrathin midsagittal sections of portions of the vermis around the fissura prima were counterstained with lead citrate and uranyl acetate and observed with a Jeol Jem $100 \mathrm{~B}$ electron microscope.

\section{Results.}

Animal growth. - With the two methods of food deprivation used the mean body weight of the undernourished animals was about 35 to 40 p. 100 below normal at 5 days of age, and 50 to 60 p. 100 below at 21 days. Mean body weight was reduced by about 15 p. 100 on the day of birth in animals undernourished by quantitative restriction of the mother's diet from day 6 of gestation.

Morphological maturation of cerebellar Bergmann glia cells. - The percentages of Bergmann glia cells, characterized by the morphological features of the 5 developmental stages previously defined (fig. 1), were plotted on figure 2 according to animal age. In both groups stage I completely disappeared at 14 days of age; at 21 days stage II was also entirely lacking. The most striking difference between the controls and the under-
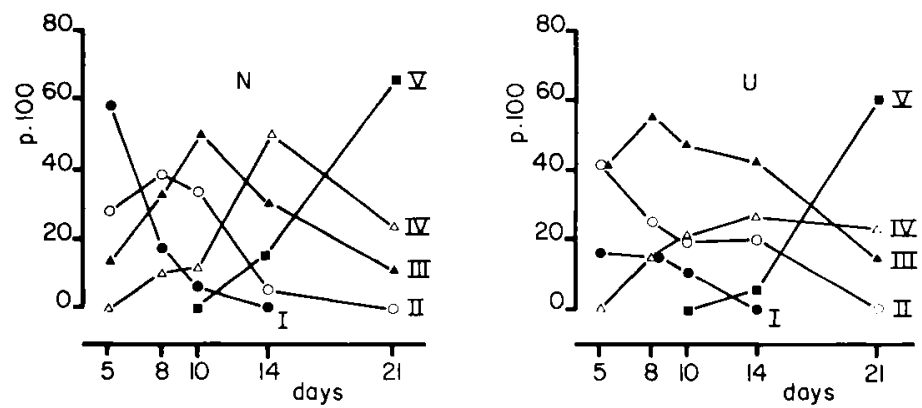

FIG. 2. - The percentages of Bergmann glia cells displaying the morphological features characteristic of the 5 developmentol stages shown in figure 1 are plotted against age of the normal (N) and undernourished (U) animals. 
nourished animals was observed at the early age studied (5 days), i. e. the cells in stage I of development represented about 60 p. 100 of the tolal cell population in the controls against less than 20 p. 100 in the undernourished rats. The latter also displayed higher percentages of cells in stages II and III of development. Between 5 and 8 days of age the percentage of cells in stage II was stili increasing in the controls, whereas it was already decreasing in the undernourished rats. Thus, the most immoture stages (I and II) disappeared early in the undernourished subjects less than 8 days old. The same trend was observed for stage III, which was maximally represented at 8 days of age in the undernourished rats vs. 10 days in controls. Apporently, the morphological maturation of Bergmann glia cells was advanced in the undernourished rats during the first postnatal week. Conversely, at 15 days of age more examples of stages II and III were found in undernourished rats than in controls, and the most mature stages (IV and V) constituted lower percentages of the total Bergmann cell population. This indicated apparent retarded maturation at the Bergmann glia cell level. Finally, at 21 days of age the three most mature stages (III, IV, V) were about equally represented. The development of Bergmann glia was not then achieved in either group of animals. Electron micrographs of the cerebellar cortex of 5-day-old animals confirmed that the morphological maturation of Bergmann glia was advanced in the underncurished rats during the first postnatal week ; the growth cones of the Bergmann processes reaching the pia mater were shown to be more numerous in undernourished subjects than in controls (fig. 3).

\section{Discussion.}

Our observations on the normal development of Bergmann glia cells agree with those of Das (1976). We were surprised and interested to find that in the early postnatal period food deprivation apparently accelerated morphogenesis of these cells. The cerebellum DNA content in undernourished subjects was rapidly reduced and there was a final cell deficit, especially in various glial populations ; cell counts in Nissl preparations of the cerebellar cortex of 35-day old undernourished rats have particularly shown that undernutrition leads to a marked reduction in the number of Bergmann glia cells (Clos et al., 1977). The Bergmann cells could not be counted in our Golgi-Cox preparations, and it is possible that their number may have already been reduced during the early postnatal period. The apparent acceleration of their morphogenesis during this period may have consequently only reflected a decrease in the newly formed ones. However, electron microscope observations of the cerebellar cortex at 5 days of age clearly showed that infiltration of the molecular and external granular layers by Bergmann glia fibers was accelerated. Preliminary results in our laboratory indicate that neonatal hyperthyroidism, which accelerates cell maturation and results in a final deficit of cells throughout the brain (for review see Legrand, 1977), affects Bergmann glia cell morphogenesis in a way similar to that of undernutrition, whereas fetal and neonatal thyroid deficiency, leading to an increase in the number of Bergmann glia cells (Clos and Legrand, 1973) has the reverse effects on the maturation of these cells (unpublished). In comparison with the well-fed controls, undernourished pups, as the hyperthyroid rats, display early high locomotor activity. 


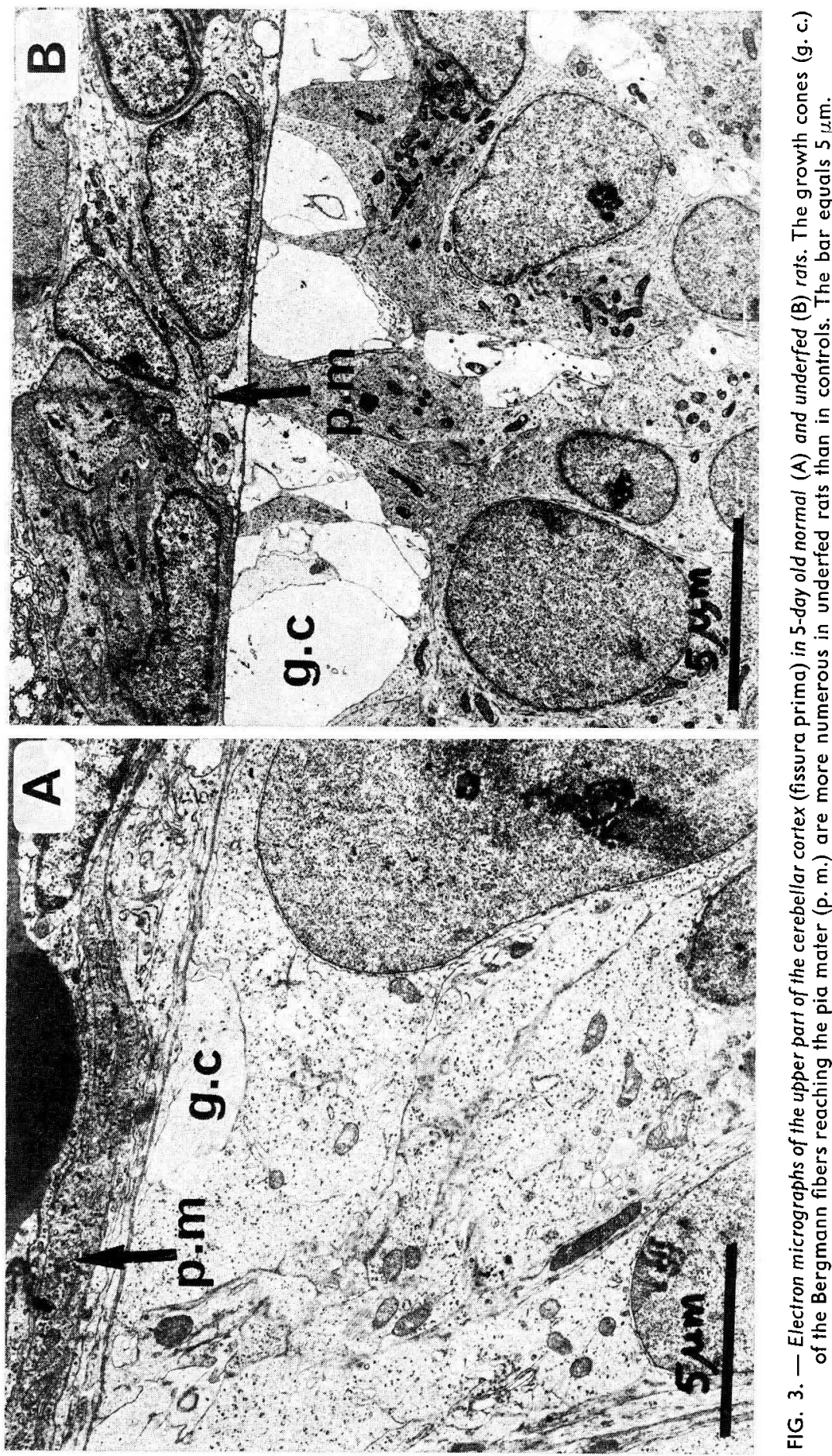


The resemblance between the effects of food deprivation and those of hyperthyroidism on Bergmann glia cells furnishes further arguments in favor of an early transient acceleration of their development in undernourished animals, subsequently leading to a reduction of their number.

4e Réunion du groupe Développement I.N.R.A., Montpellier, 17-18 mai 1978.

Acknowledgments. - The authors are indebted to Mr. F. Caruso and Mrs C. Aimar for their skilled technical assistance. This work was supported by the DGRST (grant no 77-7-0965) and the INSERM (grant no 75-1-204-6).

Résumé. La morphogenèse des cellules gliales de Bergmann, qui pourraient jouer un rôle important au cours de l'histogenèse du cortex cérébelleux, a été étudiée sur des préparations Golgi-Cox ef sur des micrographies de cervelef de jeunes rats normaux ef sousalimentés. Une accélération du développement morphologique des cellules gliales de Bergmann a été observée chez les animaux sous-alimentés au début de la période postnatale.

\section{References}

CLOS J., 1978. Hormonal and nutritional effects on the development of glia. 247-256, In SCHOFFENIELS E., FRANCK G., HERTZ L., TOWER D. B. Dynamic properties of glia cells, Pergamon Press, New York.

CLOS J., FAVRE C., SELME-MATRAT M., LEGRAND J., 1977. Effects of undernutrition on cell formation in the rat brain and specially on cellular composition of the cerebellum. Brain Res., 123, 13-26.

CLOS J., LEGRAND J., 1973. Effects of thyroid deficiency on the different cell populations of the cerebellum in the young rat. Brain Res., 63, 450-455.

CLOS J., REBIËRE A., LEGRAND J., 1973. Differential effects of hypothyroidism and undernutrition on the development of glia in the rat cerebellum. Brain Res., 63, 445-449.

DAS G. D., 1976. Differentiation of Bergmann glia cells in the cerebellum : a golgi study. Brain Res., 110, 199-213.

GOURDON J., CLOS J., COSTE C., DAINAT J., LEGRAND J., 1973. Comparative effects of hypothyroidism, hyperthyroidism and undernutrition on the protein and nucleic acid contents of the cerebellum in the young rat. J. Neurochem., 21, 861-871.

LEGRAND J., 1977. Morphological and biochemical effects of hormones on the developing nervous system in Mammals, 137-164. In BERENBERG S. R. Brain : fetal and infont. Current research on normal and abnormal development, Martinus Nijhoff Med. Div., The Hague.

PATEL A. J., BALAZS R., JOHNSON A. L., 1973. Effect of undernutrition on cell formation in the rat brain. J. Neurochem., 20,1151-1165.

RAKIC P., 1971. Neuron-glia relationship during granule cell migration in developing cerebellar cortex. A Golgi and electron microscopic study in Macacus rhesus. J. comp. Neurol., 141, 283 312.

SOTELO C., CHANGEUX J. P., 1974. Berg nann fibers and granular cell migration in the cerebellum of homozygous weaver mutant mouse. Brain Res., 77, 484-491.

SWARZ J. R., DEL CERRO M., 1976. An electron microscopic and Golgi study of the external granular layer in fetal mouse cerebellum. Neurosci. Abstr., vol. II, parts 1 and 2.

WURTMAN R. J., WURTMAN J. J., 1977. Nutrition and the brain, vol. 2, Raven Press, New York. 